\title{
TINJAUAN YURIDIS EKSEKUSI PIDANA MATI DI INDONESIA
}

\author{
Paulinus Soge \\ Fakultas Hukum Universitas Atma Jaya Yogyakarta \\ Email: soge@mail.uaivac.id
}

\begin{abstract}
From the juridical perspective, execution of death penalty in Indonesia is carried out by firing to death based on Law No. 2 Pnps 1964. Such a method was stressed again by Constitution Court in its sententce No. 21/PUU-VI/2008 which refused to change method of execution with the other one that would not be a torture for the condemned as requested by those condemned of death penalty in Bali bomb case, Amrosi and his friends. The Contitution Court considered that execution of death penalty based on this law has the risk of unaccuracy which can cause pain, but it is not a torture meant by Article 28I of the 1945 Constitution.
\end{abstract}

Keywords: death penalty execution, fired to death, not a torture.

\begin{abstract}
Abstrak
Eksekusi pidana mati di Indonesia ditinjau dari perspektif yuridis dilaksanakan dengan ditembak sampai mati berdasarkan UU No. 2 Pnps Tahun 1964. Hal ini ditegaskan kembali oleh Mahkamah Konstitusi (MK) dalam putusan No. 21/PUU-VI/2008 yang menolak mengganti cara eksekusi pidana mati dengan cara lain yang bersifat tidak menyiksa terpidana sebagaimana dimohon oleh para terpidana mati kasus bom Bali, Amrozi dan teman-temannya. MK berpendapat bahwa eksekusi pidana mati berdasarkan Undang Undang ini mengandung risiko terjadinya ketidaktepatan dalam pelaksanaan yang menimbulkan rasa sakit, namun hal itu bukan merupakan penyiksaan sebagaimana dimaksud Pasal 28I UUD 1945.
\end{abstract}

Kata kunci: eksekusi pidana mati, ditembak sampai mati, bukan penyiksaan.

\section{A. Pendahuluan}

Dari perspektif sejarah hukum dapat diketahui bahwa pidana mati telah dikenal bersamaan dengan adanya manusia di muka bumi ini. Pidana mati telah dikenal sejak zaman Nabi Musa, Yunani kuno, dan kekaiseran Romawi. Pada zaman Yunani kuno, pidana mati diterapkan terhadap Socrates tahun 399 sebelum Masehi dengan menggunakan racun (Lilik Mulyadi, 2007: 288). Pada zaman kekaisaran Romawi, pidana mati diterapkan antara lain untuk mencegah menyebarluasnya agama Katholik dan juga untuk hiburan bagi warga kota Roma. Kaisar Nero yang hidup pada abad pertama terkenal sangat kejam terhadap penganut agama Katholik. Banyak pengikut ajaran Katholik yang dengan sungguh percaya kepada Tuhan dan tidak takut mempertahankan agamanya, dimasukkan ke dalam kandang harimau dan serigala yang kelaparan, agar diterkam dan menjadi santapan hewan-hewan buas itu di suatu arena yang dapat disaksikan oleh ribuan warga kota Roma (Syamsul Hidayat, 2010: 40).

Beccaria dalam tulisannya pada paruh kedua abad ke-18 yang berjudul "Dei Deliti e delle Pene" dengan keras menentang pidana mati. Dalam tulisannya tersebut beliau menganjurkan agar penerapan pidana mati seyogyanya juga mempertimbangkan kemanusiaan. Dia meragukan hak negara untuk menjatuhkan pidana mati. Keraguannya didasarkan pada teori perjanjian sosial bahwa satu-satunya alasan untuk menghukum adalah menjamin keberlansungan kehidupan masyarakat dan mencegah orang untuk melakukan kejahatan. Pidana mati tidak dapat mencegah kejahatan dan bahkan merupakan kebrutalan. Menurut Beccaria pidana mati tidak menghargai sumber daya manusia yang merupakan modal utama Negara (Syamsul Hidayat, 2010: 41-42). Perjuangan keras Beccaria akhirnya berhasil mempengaruhi beberapa peraturan hukum pada jamannya. Hukum Pidana Belanda menghapuskan pidana mati pada tanggal 17 September 1870 dengan Stb. 162. Tahun 1880 ketika Belanda mulai memperbaharui hukum pidananya, pidana mati diperdebatkan lagi, namun akhirnya diputuskan menolak pidana mati (Roeslan Saleh, 1978: 8). Karena itu dalam Wetbooek van Straaftrecht (WvS) Belanda tidak ada pengaturan tentang pidana mati. 
Ketika WvS dibawa ke Indonesia dan mulai digunakan pada tanggal 1 Januari 1918, bersamaan dengan kolonisasi Belanda, maka berdasarkan asas konkordansi, pidana mati diatur dalam Pasal 10 KUHP sebagai salah satu sanksi pidana pokok. Menurut beberapa pakar hukum pidana, pidana mati dipertahankan pada saat itu karena kondisi khusus di Indonesia memerlukan jenis pidana yang keras ini untuk melawan para penjahat kelas kakap yang menyebar di seantero wilayah Indonesia. Dalam suatu daerah yang begitu luas dihuni oleh beraneka ragam penduduk, kepolisian negara yang jumlahnya sangat terbatas jelas tidak mampu menjamin keamanan seperti halnya di Eropa (Andi Hamzah and Sumangilepu, 1983: 23). Selain itu, menurut para pendukungnya, pidana mati tidak hanya dilihat dari kepentingan si terpidana, tetapi juga harus dilihat dari kepentingan si korban dan keluarganya pada khususnya dan masyarakat pada umumnya. Sebaliknya para penentang pidana mati berpendapat bahwa pidana mati tidak manusiawi karena terpidana tidak dapat direhabilitasi di dalam masyarakat (Abu Tamrin, 2012: 2).

Kontroversi mengenai pidana mati tidak hanya terjadi di Indonesia, tetapi juga di seluruh dunia. Bertolak dari kontroversi tersebut beberapa negara telah menghapus pidana mati (abolisionists), tetapi beberapa negara masih mempertahankannya (retentionists). Data mengenai pengaturan pidana mati sampai dengan akhir Agustus 1987 dapat dilihat pada tebel 1 sebagai berikut (Muladi 1989: 1).

Table 1. Pengaturan Hukum Berkait Pidana Mati di antara Negara-negara sampai

Akhir Agustus 1987

\begin{tabular}{|c|l|c|}
\hline No. & \multicolumn{1}{|c|}{$\begin{array}{l}\text { Status Negara-negara } \\
\text { Berkait Pidana Mati }\end{array}$} & Jumlah \\
\hline 1. & $\begin{array}{l}\text { Negara-negara yang secara } \\
\text { mutlak menghapus pidana } \\
\text { mati }\end{array}$ & 32 \\
\hline 2. & $\begin{array}{l}\text { Negara-negara yang } \\
\text { mengancam dengan pidana } \\
\text { mati hanya terhadap } \\
\text { kejahatan-kejahatan tertentu }\end{array}$ & 18 \\
\hline 3. & $\begin{array}{l}\text { Negara-negara yang secara } \\
\text { de facto telah menjadi } \\
\text { abolitionists sejak 1976 }\end{array}$ & 16 \\
\hline 4. & $\begin{array}{l}\text { Negara-negara yang } \\
\text { dianggap sebagai } \\
\text { retentionists (termasuk } \\
\text { Indonesia) }\end{array}$ & 110 \\
\hline 5. & $\begin{array}{l}\text { Negara-negara yang telah } \\
\text { menghapuskan pidana mati } \\
\text { sejak 1975 (baik untuk } \\
\text { kejahatan-kejahatan tertentu } \\
\text { maupun kejahatan pada } \\
\text { umumnya) }\end{array}$ & \\
\hline
\end{tabular}

Yustisia Vol.1 No. 3 September-Desember 2012
Selanjutnya, menurut data Amnesti International (Lilik Mulyadi, 2007: 288), pengaturan hukum berkait pidana mati di antara negara-negara dapat dilihat dalam tabel 2 sebagai berikut .

Table 2. Pengaturan Hukum Berkait Pidana Mati di antara Negara-negara

\begin{tabular}{|l|l|c|}
\hline No. & \multicolumn{1}{|c|}{$\begin{array}{l}\text { Status negara-negara } \\
\text { berkaitan dengan pidana } \\
\text { mati }\end{array}$} & Jumlah \\
\hline 1. & $\begin{array}{l}\text { Negara-negara yang tidak } \\
\text { menerapkan pidana mati } \\
\text { untuk semua kejahatan }\end{array}$ & 80 \\
\hline 2. & $\begin{array}{l}\text { Negara-negara yang tidak } \\
\text { menerapkan pidana mati } \\
\text { hanya dalam keadaan perang }\end{array}$ & 15 \\
\hline 3. & $\begin{array}{l}\text { Negara-negara yang masih } \\
\text { mencantumkan pidana mati } \\
\text { dalam hukum mereka, tetapi } \\
\text { sejak sepuluh tahun terakhir } \\
\text { tidak menerapkannya. }\end{array}$ & 118 \\
\hline 4. & $\begin{array}{l}\text { Negara-negara yang masih } \\
\text { menerapkan pidana mati } \\
\text { seperti Indonesia, Thailand, } \\
\text { Malaysia, Singapore, Vietnam, } \\
\text { Philipina dll. }\end{array}$ \\
\hline
\end{tabular}

wa telah terjadi perubahan signifikan di sejumlah negara baik yang abolitionists maupun retentionists dalam delapan belas tahun terkahir (1987 s.d. 2007). Pada 1987 hanya terdapat 32 negara yang secara absolut menghapus pidana mati, tetapi pada 2007 terdapat 80 negara yang menghapus pidana mati. Sebaliknya, pada 1987 terdapat 118 negara yang dianggap sebagai retentionists termasuk Indonesia, sementara pada 2007 terdapat 78 negara yang masih menerapkan pidana mati termasuk Indonesia.

Dengan demikian, pidana mati telah menjadi kenyataan dan keberadaaannya tidak dapat dipisahkan dari nilai-nilai sosial dan budaya suatu negara. Oleh karena itu, menurut Muladi upaya yang harus dilakukan oleh berbagai negara di dunia adalah bagaimana membuat pengaturan hukum agar eksekusi pidana mati menjadi lebih manusiawi (Muladi, 1989: 1-2), . Berkait usaha ini dikenal upaya yang disebut dengan "The Safeguard Guaranteeing Protection of the Rights of Those Facing Death Penalty" yang diterima ECOSOC PBB tahun 1984 yang berisi sembilan butir sebagai berikut.

1. Di negara-negara yang belum menghapus pidana mati, pidana mati hanya dikenakan untuk kejahatan-kejahatan yang paling serius. Perlu dipahami bahwa lingkup kejahatankejahatan tersebut tidak melampaui kejahatan- 
kejahatan yang disengaja dengan konsekuensi disuntik mati atau konsekuensi-konsekuensi sangat berat lainnya.

2. Pidana mati hanya dapat diterapkan pada suatu kejahatan yang oleh hukum diatur dengan pidana mati pada saat kejahatan tersebut dilakukan, perlu dibuat peraturan hukum untuk pengenaan pidana yang lebih ringan, dengan demikian pelaku kejahatan dapat memperoleh manfaat.

3. Mereka yang berusia di bawah 18 tahun ketika melakukan kejahatan tidak boleh dijatuhi pidana mati, begitu pun pidana mati tidak boleh dikenakan terhadap perempuan hamil, ibu yang baru melahirkan, atau orang gila.

4. Pidana mati hanya dapat dikenakan apabila yang didakwakan kepada orang tersebut didasarkan pada bukti yang jelas dan meyakinkan dan tidak ada alternatif lain yang dapat menjelaskan kenyataan tersebut.

5. Pidana mati hanya dapat dilaksanakan berdasarkan putusan akhir yang dijatuhkan oleh pengadilan yang kompeten setelah melalui proses hukum yang memberikan semua perlindungan yang mungkin untuk menjamin peradilan yang jujur, sekurangkurangnya sepadan dengan apa yang diatur dalam Pasal 14 Konvensi Internasional mengenai Hak-Hak Sipil dan Politik, termasuk telah dipenuhinya hak tersangka atau terdakwa yang dapat dikenakan pidana mati untuk mendapatkan bantuan hukum yang memadai pada semua tahap dalam proses peradilan.

6. Seseorang yang dijatuhi pidana mati harus diberi hak untuk mengajukan banding ke pengadilan yang lebih tinggi tingkat kewenangannya, dan langkah-langkah harus diambil untuk menjamin pengajuan banding tersebut.

7. Seseorang yang dijatuhi pidana mati harus mempunyai hak untuk mendapatkan pengampunan, atau pergantian hukuman pengampunan atau pergantian pidana dapat diberikan pada semua kasus yang dapat dikenai pidana mati.

8. Pidana mati tidak boleh dikenakan tergantung pada pengajuan banding atau proses hukum lainnya berkaitan dengan pengampunan atau pergantian pidana.

9. Manakala pidana mati harus dijatuhkan, pelaksanaannya harus memberikan penderitaan yang seminimal mungkin.

Bertolak dari sembilan butir upaya yang dicanangkan oleh "The Safeguard Guaranteeing Protection of the Rights of Those Facing Death Penalty"dan telah diterima ECOSOC PBB tahun
1984 untuk dilakukan oleh berbagai negara di dunia agar eksekusi pidana mati menjadi lebih manusiawi, maka penulis mengkaji eksekusi pidana mati di Indonesia. Permasalahannya ialah, apakah eksekusi pidana mati di Indonesia sesuai atau sejalan dengan semangat yang ada dalam sembilan butir "The Safeguard Guaranteeing Protection of the Rights of Those Facing Death Penalty" ?, Lebih khusus lagi, apakah eksekusi pidana mati di Indonesia merupakan penyiksaan sehingga menjadi kurang manusiawi?

\section{B. Eksistensi Pidana Mati di Indonesia}

Menurut Muladi (Muladi, 1989: 5), eksistensi pidana mati harus didasarkan pada beberapa konsep teoretis mengenai tujuan pemberian sanksi pidana seperti teori retributif, teori teleologis dan teori retributif teleologis. Menurut para pendukung teori retributif pemberian sanksi pidana terhadap orang yang telah melakukan tindak pidana itu adil karena akan memperbaiki keseimbangan moral yang telah dirusak oleh kejahatan. Orang baik akan berbahagia dan orang jahat akan menderita karena perilakunya yang jahat. Akan terjadi ketidakseimbangan apabila pelaku kejahatan gagal mendapatkan penderitaan karena perbuatan jahatnya. Keseimbangan moral akan tercapai apabila pelaku kejahatan diberi sanksi pidana dan korban mendapatkan kompensasi.

Sementara itu, menurut para penganjur teori teleologis, sanksi pidana dapat diberikan untuk memperoleh kemanfaatan. Pemberian sanksi pidana pelaku kejahatan dapat menjadikannya seorang yang lebih baik dan sekaligus dapat mencegah penjahat yang petensial agar dunia menjadi tempat yang lebih baik. Kejahatan dianggap sebagai sakit jiwa dan dapat disembuhkan dengan obat yang tidak menyenangkan, yaitu sanksi pidana. Para pemikir teori teleologis menyatakan bahwa subyek moral harus mempunyai pilihan bahwa tindakannya dapat mempunyai kemanfaatan maksimum. Kemanfaatan suatu tindakan dapat diukur dari keberhasilannya menciptakan kebahagiaan atau mengurangi penderitaan bagi setiap orang.

Selanjutnya, menurut para penganjur teori retributif teleologis, tujuan pemberian sanksi pidana itu jamak karena berkaitan dengan prinsip-prinsip teleologis dan retributif dalam suatu kesatuan, oleh karena itu teori ini juga disebut teori integratif. Teori ini menganjurkan kemungkinan untuk mengintegrasikan beberapa fungsi sekaligus: fungsi retributif dan fungsi kemanfaatan, misalnya pencegahan dan rehabilitasi, yang harus dikombinasikan sebagai target yang diterima melalui perencanaan dalam memberikan sanksi pidana. Sanksi pidana harus menjadi sarana 
untuk mengasimilasikan narapidana agar mereka dapat kembali dan hidup bersama dengan warga lainnya di dalam masyarakat. Berkaitan hal ini dapat dikatakan bahwa pidana merupakan suatu seni.

Di antara ketiga teori tersebut, teori integratif mengenai tujuan pemberian sanksi pidana cocok untuk Indonesia karena sekarang ini pemberian sanksi pidana sangat rumit sebagai akibat dari upaya-upaya yang mengarahkan perhatian terhadap faktor-faktor yang berkaitan dengan HAM dan menjadikan sanksi pidana menjadi operasional and fungsional (Muladi, 1989: 5). Pilihan teori integratif mengenai tujuan pemberian sanksi pidana didasarkan pada beberapa alasan, seperti alasan ideologis, sosiologis and yuridis.

Secara ideologis Indonesia adalah negara yang berdasarkan pada Pancasila. Berkaitan pidana mati, baik penganjur maupun penentang pidana mati mendasarkan pemikiran mereka pada Pancasila. Fenomena ini dapat dilihat dari hasil penelitian yang dilakukan tahun 1981/1982 oleh Fakultas Hukum UNDIP yang berkolaborasi dengan Kejaksaan Agung RI. Penelitian tersebut melaporkan bahwa "ada kecenderungan baik penganjur maupun penentang pidana mati menggunakan Pancasila sebagai "justifikasi" (Syamsul Hidayat, 2010: 5).

Berkaitan alasan sosiologis, G. Peter Hoefnagels sebagaimana dikutip Muladi (Muladi, 1989: 10) menyatakan bahwa permasalahan utama kejahatan dan sanksi pidana berada di luar hukum dan dapat ditemukan dalam realitas manusia dan masyarakat. Oleh karena itu, pendekatan dasar yang digunakan menelusuri permasalahan kejahatan dan pemberian sanksi pidana bukanlah pendekatan hukum tetapi pendekatan dalam konteks manusia dan masyarakat sesuai kondisi sosial masyarakat Indonesia. Dari berbagai literature, baik yang ditulis para pakar asing maupun Indonesia, dapat diketahui bahwa esensi manusia dalam konteks hubungannya dengan masyarakat pada umumnya memberikan prioritas terhadap keseimbangan. Manusia adalah bagian alam dan keberadaannya tidak dapat dipisahkan dari kesatuan dan keseluruhan alam semesta. Segala sesuatu saling berhubungan dan mempengaruhi. Dalam hal ini, yang paling penting bagi masyarakat ialah adanya keseimbangan dan keharmonisan antara dunia fisik dan mistik, antara manusia secara keseluruhan dan individu, antara persekutuan dan teman di dalam masyarakat.

Menurut Friedman, (Lawrence M. Friedman, 1977: 6-7), sistem hukum dapat dibagi menjadi tiga sub sistem: struktur hukum, substansi hukum, dan budaya hukum. Struktur hukum berkaitan dengan badan, kerangka dan bentuk suatu sistem; substansi hukum menentukan peraturan dan norma yang digunakan oleh lembaga-lembaga, kenyataan dan perilaku individu yang diamati dalam sistem; dan budaya hukum mencakup pandangan, perilaku, keyakinan, harapan dan ide-ide tentang hukum. Berkaitan sistem hukum disadari bahwa pandangan tradisional bangsa Indonesia mengenai manusia dan masyarakat dapat menciptakan hukum adat (adatrecht) dengan berbagai aspek, dan salah satunya adalah aspek pidana. Dari aspek ini, antara lain dapat dipelajari bahwa pidana mati yang dahulu digunakan untuk mengembalikan keseimbangan yang dirusak oleh beberapa kejahatan adat yang serius dalam berbagai suku di Indonesia, dieksekusi dengan berbagai cara antara lain si terpidana dibakar hidup-hidup pada sebuah tiang, dibunuh dengan menggunakan keris, dicap dengan besi panas, digantung pada pohon bambu yang melengkung agar dimakan oleh burung-burung, dipenggal kepalanya dengan pedang, dirajam dengan batu sampai mati, dan seterusnya.

Berdasarkan alasan yuridis, sebagaimana telah diuraikan di atas bahwa ketika $W v S$ dibawa ke Indonesia dan mulai digunakan tanggal 1 Januari 1918, bersamaan dengan kolonisasi Belanda berdasarkan asas konkordansi, pidana mati diatur dalam Pasal 10 sebagai salah satu sanksi pidana. Oleh karena itu, di dalam KUHP terdapat beberapa kejahatan yang diancam dengan pidana mati sebagai berikut (R. Sugandhi, 1981: 14).

1. Makar membunuh kepala negara (Pasal 104)

2. Mengajak Negara Asing guna menyerang Indonesia (Pasal 111 ayat $\{2\}$ ).

3. Memberi pertolongan pada musuh waktu Indonesia dalam keadaan perang (Pasal 124 ayat $\{3\})$.

4. Membunuh Kepala Negara sahabat (Pasal 140 ayat $\{4\}$ ).

5. Melakukan pembunuhan dengan direncanakan terlebih dahulu (Pasal 140 ayat $\{3\}$ dan Pasal 340).

6. Pencurian dengan kekerasan oleh dua orang atau lebih berkawan, pada waktu malam atau dengan jalan membongkar dan sebagainya, yang menyebabkan ada orang terluka berat atau mati (Pasal 365 paragraph $\{4\}$ ).

7. Melakukan pembajakan di laut, di pesisir, di pantai dan di sungai, sehingga menyebabkan ada orang mati (Pasal 444).

8. Dalam waktu perang menganjurkan huru-hara, pemberontakan dan sebagainya antara pekerjapekerja dalam perusahaan pertahanan negara (Pasal 124 bis). 
9. Dalam waktu perang menipu ketika menyampaikan keperluan angkatan perang (Pasal 127 dan 129).

10. Pemerasan dengan pemberatan (Pasal 368 ayat\{2\}).

Di luar KUHP pidana mati tercantum dalam berbagai Undang-Undang, antara lain UndangUndang Pemberantasan Tindak Pidana Korupsi, Undang-Undang Tindak Pidana Narkotika, UndangUndang Tindak Pidana Terorisme, dan lain-lainnya.

Berkait alasan yuridis, Barda Nawawi Arief (sebagaimana dikutip Syamsul Hidayat, 2010, 56) menjelaskan bahwa pernyataan dalam UUD 1945 dan Undang Undang HAM bahwa "setiap orang mempunyai hak untuk hidup" mirip dengan Pasal 6 ayat (1) ICCPR yang menentukan bahwa "setiap manusia mempunyai hak untuk hidup". Tetapi, Pasal 6 ayat (1) tersebut dilanjutkan dengan kalimat yang tegas bahwa "Tak seorang pun dicabut nyawanya secara sewenang-wenang". Oleh karena itu, meskipun Pasal 6 ayat (1) ICCPR menyatakan bahwa "setiap orang mempunyai hak untuk hidup" tidak harus berarti bahwa hak hidupnya tidak dapat dicabut. Yang jelas dilarang adalah "mencabut hak hidup seseorang secara sewenang-wenang". Bahkan dalam Pasal 6 ayat (2) dinyatakan bahwa pidana mati masih dimungkinkan untuk "kejahatankejahatan yang sangat serius". Penjelasan Barda Nawawi Arief tentang Pasal 6 ayat (1) ICCPR tersebut identik dengan pendapat ahli hukum dan pelapor khusus PBB untuk penyiksaan, Manfred Nowak (Komisi Nasional Hak Asasi Manusia, 2008:

6) yang menyatakan bahwa kewajiban untuk menghormati hak hidup sebagaimana tertuang dalam Pasal 6 ayat (1) ICCPR bersifat tidak absolut. Dalam hal ini hanya 'pencabutan/perampasan hak hidup secara sewenang-wenang' yang dipandang melanggar Pasal 6. Menurut Sir Negel Ridley (Komisi Nasional Hak Asasi Manusia, 2008: 6-7), bahwa pidana mati dapat dinyatakan sesuai ketentuan Pasal 6 ICCPR apabila diatur oleh hukum nasional. Namun demikian, menurut Nowak, kata keterangan 'secara sewenang-wenang/arbitrarily' juga harus dimaknai lebih jauh. Arbitrarily deprivation of life mengandung unsur ketidaksahan/ unlawfulness dan tidak adil/injustice. Dengan demikian, hukum nasional yang memuat ketentuan pidana mati harus pula memenuhi ketentuan tersebut dan tidak mengandung unsur-unsur ketidaksahan dan bersifat tidak adil. Oleh karena itu, frasa 'tidak seorang pun dapat dirampas hak hidupnya secara sewenang-wenang' dalam Pasal 6 ICCPR menunjukkan bahwa 'sewenangwenang/arbitrarily' bermakna baik secara tidak sah/illegally maupun tidak adil/unjustly. Ditegaskan pula bahwa frasa tersebut meminta pula tidak adanya unsur tak dapat dijadikan pegangan (capriciousness) dan ketakmasukalanan (unreasonableness). Jadi, sekalipun pidana mati diperbolehkan asalkan diatur berdasarkan hukum nasional, tetapi hukum tersebut haruslah sah (legal), adil (just), dapat dijadikan pegangan dan juga masuk akal.

Oleh karena itu, menurut (Komnas HAM, 2008: 7) ketentuan tentang hak hidup yang termuat dalam Pasal 6 ayat (1) ICCPR tersebut tidak dapat ditafsir begitu saja sebagai larangan terhadap pidana mati. Menurut ketentuan ini, pidana mati sebagai pencabutan hak hidup masih diakui adanya jika diatur melalui hukum nasional yang adil, sah, dapat dipegang, dan juga masuk akal.

Selanjutnya, dijelaskan bahwa Pasal 6 ayat (1) masih mengakui pidana mati juga mengingat adanya ketentuan-ketentuan yang mengikutinya mengatur pembatasan terhadap pidana mati. Ketentuan-ketentuan yang mengikuti Pasal 6 ayat (1), yaitu Pasal 6 ayat (2) s.d. (6) adalah.

(2) Di negara-negara yang belum menghapuskan pidana mati, putusan pidana mati hanya dapat dijatuhkan terhadap kejahatan yang paling berat sesuai dengan hukum yang berlaku pada saat dilakukannya kejahatan tersebut, dan tidak bertentangan dengan Kovenan ini dan Konvensi tentang Pencegahan dan Penghukuman Kejahatan Genosida. Pidana mati hanya dapat dilaksanakan atas dasar putusan akhir yang dijatuhkan oleh pengadilan yang berwenang (competent).

(4) Siapapun yang dijatuhi pidana mati mempunyai hak untuk mendapatkan pengampunan atau keringanan pidana. Amnesti, pengampunan atau pengurangan pidana mati dapat diberikan dalam semua kasus.

(5) Pidana mati tidak dapat dijatuhkan atas kejahatan yang dilakukan oleh seseorang di bawah usia delapan belas tahun, dan tidak dapat dilaksanakan pada perempuan yang tengah mengandung.

(6) Tidak ada satupun dalam pasal ini yang dapat digunakan untuk menunda atau mencegah penghapusan pidana mati oleh Negara-negara Pihak pada Kovenan ini.

Eksistensi pidana mati di Indonesia ditegaskan kembali ketika MK menolak menghapus pidana mati dari sistem hukum pidana Indonesia dalam putusan MK mengenai pengujian KUHP, (Kompas, 2012: 5). MK menegaskan, pidana mati dibenarkan menurut UUD 1945 maupun Deklarasi Universal Hak Asasi Manusia. MK menolak membatalkan frasa "pidana mati" dalam Pasal 365 ayat (4) KUHP. Permohonan ini diajukan oleh dua terpidana mati Pengadilan Tinggi Pekanbaru, Raja Syahrial alias 
Herman alias Wak Ancam dan Raja Fadli alias Deli. Keduanya terbukti mencuri dengan kekerasan secara bersekutu mengakibatkan luka berat atau mati.

Para pemohon mendalilkan, pidana mati melanggar hak hidup yang dijamin Pasal 28A dan Pasal 28I UUD 1945. Para pemohon juga mendalilkan, pencurian dengan kekerasan yang menyebabkan luka berat atau mati tidak termasuk the most serious crime. Namun MK berpendapat, pencurian dengan kekerasan yang menyebabkan matinya orang merupakan the most serious crime karena menimbulkan ketakutan luar biasa pada masyarakat. Ketakutan itu sama dengan ketakutan karena narkoba.

Terkait pidana mati yang dinilai melanggar Pasal 28A dan Pasal 28I, MK melakukan penafsiran sistematis terhadap hal tersebut. Hak asasi dalam dua pasal tersebut haruslah tunduk pada pembatasan hak yang diatur Pasal 28J UUD 1945. Sistematika ini sejalan dengan Deklarasi HAM Universal yang mnempatkan HAM sebagai pasal penutup. MK pernah menolak menghapus pidana mati pada 30 Oktober 2007 saat menguji permohonan penyelundup heroin "Bali Nine" yang dipidana mati.

Sampai sekarang dari aspek yuridis Indonesia merupakan negara retensionist berkaitan pidana mati. Namun demikian menurut (Muladi, 1989: 24), baik para penganjur maupun penentang pidana mati sama jumlahnya di dalam masyarakat. Oleh karena itu, untuk menjaga keseimbangan perasaan kedua kelompok tersebut di masa yang akan datang khususnya di dalam konsep KUHP baru, pidana mati masih tetap dipertahankan tetapi ditempatkan di luar sanksi pidana pokok sebagai sanksi pidana pokok yang bersifat khusus. Pengaturan yang demikian itu akan menunjukkan pidana mati sebagai sanksi pidana yang bersifat eksepsional. Penempatan sanksi pidana mati dalam ayat yang terpisah di luar sanksi pidana pokok adalah benar, karena merupakan suatu kompromi antara para pendukung dan penentang pidana mati. Di dalam praktek hakim harus memberikan pertimbangan yang sungguh-sungguh apabila hendak menjatuhkan pidana mati.

\section{Eksekusi Pidana Mati di Indonesia}

Berdasarkan ketentuan Pasal 270 KUHAP dapat diketahui bahwa pelaksanaan putusan pengadilan yang telah mempunyai kekuatan hukum tetap dilakukan oleh jaksa, yang untuk itu panitera mengirimkan salinan surat putusan kepadanya. Dalam pengertian yuridis, putusan pengadilan yang telah mempunyai kekuatan hukum tetap berarti, a) apabila terdakwa atau penuntut umum menerima putusan yang dijatuhkan oleh pengadilan negeri; b) apabila batas waktu untuk mengajukan banding telah lewat; c) apabila permohonan banding dicabut, dan d) apabila terpidana tidak mengajukan permohonan grasi kepada Presiden (dalam jangka waktu yang sama seperti pengajuan permohonan banding).

Pasal 11 KUHP menentukan bahwa eksekusi pidana mati, yang dijatuhkan oleh pengadilan di lingkungan peradilan umum atau peradilan militer, dilakukan dengan ditembak sampai mati, menurut ketentuan-ketentuan dalam UU No. 2 Pnps Tahun 1964. Di dalam penjelasan (R. Sugandhi, 1981: 1415). Pasal 11 KUHP dinyatakan bahwa sebelum adanya ketentuan-ketentuan dalam UU No. 2 Pnps Tahun 1964, pidana mati dilaksanakan oleh algojo di tempat penggantungan menggunakan sebuah jerat di leher terpidana mati dan mengikatkan jerat itu pada tiang penggantungan serta menjatuhkan papan tempat orang itu berdiri. Tetapi, karena ketentuan ini tidak sesuai lagi dengan perkembangan serta jiwa revolusi Indonesia maka pelaksanaan pidana mati itu dilakukan dengan ditembak sampai mati di suatu tempat dalam daerah hukum pengadilan yang menjatuhkan putusan dalam tingkat pertama.

Penjelasan R. Sugandhi di atas perlu dilengkapi dengan penjelasan (Andi Hamzah, 2011: 312-313), bahwa cara pelaksanaan pidana mati sebenarnya sudah diatur dalam Pasal $11 \mathrm{KUHP}$, yaitu dengan menggantung terpidana oleh seorang algojo namun dewasa ini tidak dilaksanakan lagi sebenarnya merupakan suatu sejarah tersendiri. Pelaksanaan pidana mati dengan menggantung terpidana menurut ketentuan Pasal 11 KUHP itu berlangsung sampai tanggal 8 Maret 1942 ketika Pemerintah Hindia Belanda menyerah kepada Jepang.

Jepang mengeluarkan suatu peraturan, yaitu Osamu Gunrei No. 1 Tahun 1942, yang menyatakan bahwa pelaksanaan pidana mati dengan jalan menembak mati terpidana. Pada waktu pendudukan Belanda sesudah Perang Dunia II usai, berlaku Stb. No. 123, yang menyatakan pelaksanaan pidana mati dengan ditembak mati. Setelah Indonesia merdeka dengan UU No. 1 Tahun 1946 yang dikeluarkan oleh RI Yogyakarta, maka dinyatakan berlaku ialah KUHP. Jadi, dengan sendirinya berlaku Pasal 11 KUHP tersebut yang menyatakan bahwa pelaksanaan pidana mati dengan cara digantung.

Berdasarkan UU No. 73 Tahun 1958, UU No. 1 Tahun 1946 dinyatakan berlaku untuk seluruh wilayah Indonesia. Jadi, sejak 29 September 1958 pidana mati seharusnya dilaksanakan dengan cara 
digantung menurut Pasal 11 KUHP. Tetapi sejak saat pelaksanaan pidana mati terhadap pelaku peristiwa Cikini tahun 1958, pidana mati dijalankan dengan cara ditembak. Begitu pula terhadap Kartosuwirjo dan Dr. Soumokil. Baru pada tahun 1964 dengan Penetapan Presiden No. 2 Tahun 1964, dikeluarkan peraturan tentang tata cara pelaksanaan pidana mati yang dijatuhkan di lingkungan peradilan umum dan militer yang dilakukan dengan ditembak mati. Berdasarkan UU No. 5 Tahun 1969 tentang Pernyataan Berbagai Penetapan Presiden dan Peraturan Presiden Sebagai Undang-Undang, Penetapan Presiden No. 2 Tahun 1964 dinyatakan menjadi UU No. 2 Pnps Tahun 1964.

Pasal 271 KUHAP menentukan bahwa dalam hal pidana mati pelaksanaannya dilakukan tidak di muka umum dan menurut ketentuan UndangUndang. Bertolak dari ketentuan Pasal 271 KUHAP tersebut, Leden Marpaung (Leden Marpaung, 2010, 217-218) menjelaskan bahwa adanya berita pidana mati pada surat kabar atau warta berita yang dibaca/diketahui masyarakat tetapi kelanjutan berita tersebut mengenai pelaksanaannya kadangkadang setelah bertahun-tahun. Hal tersebut bukan disebabkan kemauan aparat atau bukan karena aparat pelaksana mengalami hambatan tetapi semata-mata karena prosedur/tata cara pelaksanaan pidana mati harus ditempuh berdasarkan UU No. 2 Pnps Tahun 1964 dan UU No. 3 Tahun 1950 tentang Permohonan Grasi sebagaimana telah diganti dengan UU No. 2 Tahun 2002 tentang Permohonan Grasi.

Berdasarkan Pasal 2 ayat (2) UU No. 3 Tahun 1950 tentang Permohonan Grasi, jika terpidana mati tidak mengajukan grasi maka hakim atau ketua pengadilan negeri, jaksa atau kepala kejaksaan negeri harus mengajukan permohonan grasi karena jabatan sebagaimana diatur dalam Pasal 12 Undang-Undang tersebut. Dengan demikian, meskipun terpidana mati tidak mengajukan grasi, berdasarkan Pasal 13 UU No. 22 Tahun 2002 eksekusi pidana mati belum dapat dilaksanakan sebelum Keputusan Presiden tentang Penolakan Grasi diterima oleh terpidana mati.

Prosedur eksekusi pidana mati baik yang dijatuhkan oleh pengadilan umum maupun pengadilan militer harus dilaksanakan sesuai ketentuan UU No. 2 Pnps Tahun 1964, yaitu eksekusi pidana mati dilaksanakan oleh 12 orang terdiri atas satu orang perwira, satu orang bintara, dan 10 orang tamtama, di bawah komando seorang perwira. Jarak antara regu penembak dengan terpidana mati antara lima sampai 10 meter. Hanya satu senapan diisi peluru. Setelah eksekusi seorang dokter melakukan pemeriksaan untuk memastikan bahwa terdakwa sudah meninggal dan penuntut umum wajib membuat laporan mengenai eksekusi pidana mati tersebut.

Menurut (Lilik Mulyadi, 2007: 289-290), berdasarkan ketentuan Pasal 2 s.d. 16 UU No. 2 Pnps Tahun 1964 prosedur eksekusi pidana mati adalah sebagai berikut.

1. Dalam jangka waktu tiga kali 24 empat jam saat pidana mati dilaksanakan jaksa tinggi/ jaksa yang bersangkutan harus memberitahukan kepada terpidana tentang akan dilaksanakan pidana mati tersebut dan apabila terpidana hendak mengemukakan sesuatu, keterangannya, atau pesannya itu diterima oleh jaksa tinggi atau jaksa tersebut (Pasal 6 ayat \{1\}dan \{2\} UU No. 2 Pnps Tahun 1964).

2. Apabila terpidana sedang hamil, eksekusi pidana mati baru dapat dilaksanakan empat puluh hari setelah anaknya dilahirkan (Pasal 7 UU No. 2 Pnps Tahun 1964).

3. Tempat pelaksanaan pidana mati ditentukan oleh menteri kehakiman yaitu di suatu tempat dalam daerah hukum pengadilan yang menjatuhkan putusan dalam tingkat pertama (Pasal 2 ayat $\{1\} \cup U$ No. 2 Pnps Tahun 1964).

4. Kepala kepolisian dari daerah yang bersangkutan bertanggung jawab mengenai pelaksanaan pidana mati tersebut setelah mendengar nasihat dari jaksa tinggi/jaksa yang telah melakukan penuntutan pidana mati pada peradilan tingkat pertama (Pasal 3 dan 4 UU No. 2 Pnps Tahun 1964).

5. Pelaksanaan pidana mati dilakukan oleh regu penembak yang terdiri atas seorang bintara, 10 orang tamtama, di bawah pimpinan seorang perwira yang semuanya dari Brigade Mobile (Pasal 10 ayat $\{1\} \cup U$ No. 2 Pnps Tahun 1964).

6. Kepala Polisi dari daerah yang bersangkutan (atau perwira yang ditunjuk) dan jaksa tinggi/ jaksa yang bertanggung jawab harus menghadiri pelaksanaan pidana mati tersebut (Pasal 4 UU No. 2 Pnps Tahun 1964).

7. Sebelum pelaksanaan pidana mati, maka terpidana dapat disertai rohaniawan (Pasal 11 ayat $\{1\}$ UU No.2 Pnps Tahun 1964), kemudian terpidana dapat menjalani pidana mati secara berdiri, duduk atau berlutut (Pasal 12 ayat $\{1\}$ UU No. 2 Tahun 1964) dan eksekusi pidana mati dilaksanakan tidak di muka umum dan dengan cara sesederhana mungkin kecuali ditetapkan lain oleh Presiden (Pasal 9 UU No. 2 Pnps Tahun 1964).

8. Penguburan jenazah terpidana diserahkan kepada keluarganya atau sahabat terpidana kecuali berdasarkan kepentingan umum Jaksa Tinggi/Jaksa yang bersangkutan dapat 
menentukan lain (Pasal 15 ayat $\{1\}$ UU No. 2 Pnps Tahun 1964); dan

9. Kemudian setelah eksekusi pidana mati dilaksanakan, jaksa tinggi/jaksa yang bersangkutan harus membuat berita acara mengenai pelaksanaan pidana mati dan isi dari berita acara tersebut kemudian harus dicantumkan di dalam surat keputusan dari pengadilan yang bersangkutan (Pasal 16 ayat \{1\} dan \{2\} UU No. 2 Pnps Tahun 1964).

Dari tahun 1978 s.d. tahun 2005 pelaksanaan pidana mati di Indonesia dapat dilihat dalam tabel 3 sebagai berikut (Lilik Mulyadi, 2007: 291).

Tabel 3. Pelaksanaan Pidana Mati di Indonesia dari tahun 1978 s.d. 2005

\begin{tabular}{|c|l|c|c|c|} 
No. & Nama Terpidana Mati & Kasus & Pengadilan & Tahun \\
\hline 1. & Oesin Umar Baffari & Pembunuhan & Surabaya & 1978 \\
\hline 2. & Henky Tupanwael & Pembunuhan & Jakarta & 1980 \\
\hline 3. & Kusni Kasdut & Pembunuhan & Surabaya & 1980 \\
\hline 4. & Liong Wie Tong & Pembunuhan & Kerawang & 1987 \\
\hline 5. & Tan Tiang Tjoen & Pembunuhan & Kerawang & 1987 \\
\hline 6. & Serda (Pol) Adi Saputra & Pembunuhan & Surabaya & 1987 \\
\hline 7. & Katjong Laranu & Pembunuhan & Ujung Pandang & 1995 \\
\hline 8. & $\begin{array}{l}\text { Chan Ting Chong alias } \\
\text { Steven Chang }\end{array}$ & Narkotika & Jakarta Barat & 1995 \\
\hline 9. & Frederich Soru & Narkotika & Kupang & 2001 \\
\hline 10. & Gerson Pandie & Narkotika & Kupang & 2001 \\
\hline 11. & Saadon, dkk. & $\begin{array}{c}\text { Percobaan } \\
\text { pembunuhan }\end{array}$ & Jakarta Pusat & - \\
& & mantan Presiden & & \\
\hline 12. & Ayodya Prasad Chaubey & Narkotika & Medan & 2004 \\
\hline 13. & Ny. Sumiarsih & Pembunuhan & Malang & 2005 \\
\hline
\end{tabular}

Dari tabel 3 di atas tampak bahwa berkait pidana mati, Indonesia konsekuen menerapkan pidana mati sebagai negara yang retensionist. Pidana mati tetap diterapkan terhadap pelaku kejahatan yang sangat serius seperti pembunuhan berencana yang dilakukan dengan sangat sadis dan pengedaran narkotika dalam skala besar. Selain itu, pidana mati juga diterapkan kepada pelaku kejahatan terorisme, seperti Amrozi bin Nurhasyim, Ali Ghufron bin Nurhasyim als. Muklas dan Abdul Azis als. Imam Samudra dalam kasus bom Bali yang menelan banyak korban yang tidak berdosa, meskipun para terpidana mati tersebut mengajukan judicial review terhadap UU No. 2 Pnps Tahun 1964 yang akhirnya ditolak oleh MK, sehingga eksekusi pidana mati terhadap mereka tetap dilaksanakan berdasarkan ketentuan Undang Undang tersebut.

\section{Putusan MK Nomor 21/PUU-VI/2008 tentang} Eksekusi Pidana Mati

1. Duduk Perkara

Putusan MK Nomor 21/PUU-VI/2008 (MK, 2008: 1-2) berawal dari Permohonan Pengujian UU No. 2 Pnps Tahun 1964 tentang Tata Cara Pelaksanaan Pidana Mati yang Dijatuhkan Pengadilan di Lingkungan Peradilan Umum dan Militer yang telah ditetapkan menjadi Undang Undang oleh UU No. 5 Tahun 1969 terhadap UUD 1945, yang diajukan oleh Amrozi bin Nurhasyim, Ali Ghufron bin Nurhasyim als. Muklas dan Abdul Azis als. Imam Samudra dengan surat permohonan bertanggal 6 Agustus 2008 yang diterima dan terdaftar di Kepaniteraan MK pada tanggal 6 Agustus 2008, dengan registrasi perkara Nomor 21/PUU-VI/2008. 
Para pemohon pada dasarnya mengajukan Pengujian Undang Undang (PUU) tentang norma-norma yang terdapat di dalam UU No. 2 Pnps Tahun 1964 yang ditetapkan menjadi Undang Undang dengan UU No. 5 Tahun 1969 tentang Pernyataan Berbagai Penetapan Presiden dan Peraturan Presiden sebagai Undang-Undang.

\section{Permohonan Pengujian Formal}

Dalam permohonan pengujian formil (MK, 2008: 7-8), para pemohon berpendapat bahwa menurut ketentuan Pasal 51 ayat (3) huruf "a" UU MK, perihal Undang Undang yang dapat dimohonkan untuk diuji oleh MK adalah Undang Undang yang pembentukannya tidak memenuhi ketentuan berdasarkan UUD 1945. Menurut para pemohon UU No. 2 Pnps Tahun 1964 yang telah ditetapkan menjadi Undang Undang dengan UU No. 5 Tahun 1969 merupakan Undang-Undang yang pembentukannya tidak memenuhi ketentuan UUD 1945.

Adapun dalil-dalil para pemohon mengenai pengujian formil adalah sebagai berikut.

a. UU No. 2 Pnps Tahun 1964 merupakan Undang-Undang yang pembentukannya didasarkan pada Penetapan Presiden Republik Indonesia.

b. Penetapan Presiden a quo, kemudian menjadi Undang-Undang adalah karena diundangkannya UU No. 5 Tahun 1969 tentang Pernyataan Berbagai Penetapan Presiden dan Peraturan Presiden sebagai Undang Undang.

c. Penetapan Presiden a quo merupakan Penetapan Presiden yang dimaksud oleh Pasal 2 UU No. 5 Tahun 1969 yang menentukan:

"Terhitung sejak disahkannya Undang Undang ini, menyatakan Penetapanpenetapan Presiden dan Peraturanperaturan Presiden sebagaimana termaksud dalam lampiran IIA dan IIB Undang-Undang ini, sebagai UndangUndang dengan ketentuan, bahwa materi Penetapan-penetapan Presiden dan Peraturan-perauran Presiden tersebut ditampung atau dijadikan bahan bagi penyusunan Undang-Undang yang baru".

d. UU No. 2 Pnps Tahun 1964 juncto UU No. 5 Tahun 1969 adalah Undang-Undang yang pembentukannya dilakukan dengan cara disahkan oleh Presiden Republik Indonesia dengan disetujui oleh Dewan Perwakilan Rakyat Gotong Royong. e. Dewan Perwakilan Rakyat Gotong Royong (DPR-GR) bukan lembaga perwakilan rakyat sebagainana dimaksud oleh UUD 1945, karena DPRG dibentuk atas dasar Penetapan Presiden dan anggotanya juga diangkat oleh Presiden, sedang Dewan Perwakilan Rakyat (DPR) sebagaimana dimaksud oleh Pasal 19 Amandemen UUD 1945, anggotanya dipilih melalui pemilihan umum.

f. Pembentukan Undang Undang menurut UUD 1945 adalah sebagaimana tersebut dalam Pasal 20 Amandemen UUD 1945, maka pembentukan UU No. 2 Pnps Tahun 1964 juncto UU No. 5 Tahun 1969 tidak sesuai Pasal 20 tersebut.

g. Tata Cara Pelaksanaan Pidana Mati dengan cara ditembak hingga mati oleh Regu Penembak, yang selama ini dijalankan di negara Republik Indonesia merupakan tata cara yang didasarkan pada Undang-Undang yang pembentukannya tidak sesuai UUD 1945.

h. Fakta hukum, UU No. 2 Pnps Tahun 1964 yang telah diwajibkan oleh UU No. 5 Tahun 1969 untuk diadakan perbaikan/ penyempurnaan dalam arti bahwa materi penetapan tersebut dijadikan bahan penyusunan Undang-Undang baru, hingga permohonan diajukan ke MK belum pernah ada perbaikan maupun penyempurnaan terhadap Tata Cara Pelaksanaan Pidana Mati di Indonesia.

\section{Permohonan Pengujian Material}

Dalam permohonan pengujian material (MK, 2008: 8-9), para pemohon berpendapat bahwa menurut ketentuan Pasal 51 ayat (3) huruf "b" UU MK, perihal Undang Undang yang dapat dimohonkan untuk diuji oleh MK adalah Undang Undang yang materi muatan dalam ayat, pasal, dan/atau bagian Undang Undang bertentangan dengan UUD 1945. Menurut para pemohon UU No. 2 Pnps Tahun 1964 juncto UU No. 5 Tahun 1969 bertentangan dengan UUD 1945 khususnya Pasal 281 ayat (1) perubahan kedua, berdasarkan dalil-dalil sebagai berikut.

a. Pasal 281 ayat (1) menentukan:

"Hak untuk hidup, hak untuk tidak disiksa, hak kemederkaan pikiran dan hati nurani, hak beragama, hak untuk tidak diperbudak, hak untuk diakui sebagai pribadi di hadapan hukum, dan hak untuk tidak dituntut atas dasar hukum yang berlaku surut adalah hak asasi manusia 
yang tidak dapat dikurangi dalam keadaan apa pun".

b. Tata Cara Pelaksanaan Pidana Mati dengan cara ditembak hingga mati oleh regu Penembak sebagaimana ditentukan dalam UU No. 2 Pnps Tahun 1964 juncto UU No. 5 Tahun 1969, adalah penyiksaan terhadap terpidana karena dalil-dalil.

Pasal 1 UU No. 2 Pnps Tahun 1964 menentukan bahwa pidana mati dengan cara ditembak dilakukan dengan cara ditembak hingga mati. Kalimat ini menimbulkan pengertian bahwa kematian yang akan diterima oleh Terpidana tidak sekaligus terjadi dalam "satu kali tembakan", namun harus dilakukan secara berkali-kali hingga mati. Dengan demikian, terjadi penderitaan yang amat sangat sebelum terpidana akhirnya mati.

Pasal 14 ayat (4) UU No. 2 Pnps Tahun 1964 lebih memberikan penegasan atas kemungkinan tidak terjadinya kematian dalam satu kali tembakan, sehingga diperlukan tembakan pengakhir, dengan kalimat Undang-Undang:

"Apabila setelah penembakan, terpidana masih meperlihatkan tandatanda bahwa ia belum mati, maka Komandan Regu segera memerintahkan kepada Bintara regu Penembak untuk melepaskan tembakan pengakhir..."

Sebelum tembakan pengakhir tersebut berarti Undang-Undang ini mengakui bahwa terpidana masih hidup, padahal dia sudah dalam keadaan tertembak dan tentunya dalam keadaan berlumuran darah, sehingga dalam keadaan tersiksa yang amat sangat, sebelum akhirnya mati oleh tembakan pengakhir.

c. Regu Penembak yang diberi tugas untuk mengeksekusi terpidana menurut UU No.2 Pnps Tahun 1964 juncto UU No. 5 Tahun 1969, diharuskan membidik pada jantung terpidana (Pasal 14 ayat $\{3\}$ ) namun pada Pasal 14 ayat (4) menentukan untuk mengarahkan tembakan tembakan pengakhir dengan menekankan ujung laras senjatanya pada kepala terpidana tepat di atas telinganya. Dengan demikian tata cara ini tidak memberikan kepastian akan "tiadanya penyiksaan" dalam proses kematian terpidana. Jika menurut pembentuk Undang-Undang yang dapat mengakibatkan kematian langsung adalah tembakan di atas telinga terpidana mengapa ada tata cara yang mengharuskan membidik pada "jantung", artinya, pembentuk Undang-Undang tidak meyakini bahwa tembakan pada jantung akan mengakibatkan kematian langsung, sehingga ada ketentuan Pasal 14 ayat (4) tersebut.

d. Meskipun seorang warga Negara Indonesia itu statusnya adalah terpidana maka menurut UUD 1945, khususnya Pasal 281 ayat (1), tetap dijamin hak asasi manusianya, sehingga penyiksaan terhadapnya dengan menggunakan tata cara pelaksanaan pidana mati berdasarkan UU No. 2 Pnps Tahun 1964 juncto UU No. 5 Tahun 1969 materinya jelas bertentangan dengan UUD 1945.

\section{Putusan MK Nomor 21/PUU-VI/2008}

Di dalam Amar Putusan (MK, 2008: 7475) dinyatakan bahwa, dengan mengingat Pasal 56 ayat (5) UU No. 24 Tahun 2003 tentang MK (Lembaran Negara Republik Indonesia Tahun 2003 Nomor 98, Tambahan Lembaran Negara Republik Indonesia Nomor 4316) maka berdasarkan UUD 1945, MK menyatakan permohonan para pemohon baik mengenai pengujian formal maupun pengujian material ditolak untuk seluruhnya.

Putusan MK yang menolak permohonan para pemohon baik mengenai pengujian formal maupun material untuk seluruhnya karena MK menyimpulkan berdasarkan seluruh pertimbangan tentang fakta dan hukum yang diuraikan di dalam persidangan bahwa:

a. dalil-dalil para pemohon mengenai pengujian formal tidak beralasan sehingga harus ditolak;

b. rasa sakit yang dialami oleh terpidana mati merupakan konsekuensi logis yang melekat dalam proses kematian sebagai akibat pelaksanaan pidana mati terhadap terpidana sesuai tata cara yang berlaku, sehingga tidak termasuk kategori penyiksaan terhadap diri terpidana mati;

c. dari berbagai alternatif tentang tata cara pelaksanaan pidana mati selain cara ditembak, seperti digantung, dipenggal pada leher, disetrum listrik, dimasukkan ke dalam ruang gas, dan disuntik mati, semuanya menimbulkan rasa sakit meskipun gradasi dan kecepatan 
kematiannya berbeda-beda. Tidak ada satu cara pun yang menjamin tiadanya rasa sakit dalam pelaksanaannya, bahkan semuanya megandung risiko terjadinya ketidaktepatan dalam pelaksanaan yang menimbulkan rasa sakit. Namun, hal itu bukan merupakan penyiksaan sebagaimana dimaksud Pasal 28I UUD 1945, sehingga UU No. 2 Pnps Tahun 1964 tentang Tata Cara Pelaksanaan Pidana Mati yang Dijatuhkan oleh Pengadilan di Lingkungan Peradilan Umum dan Militer tidak bertentangan dengan UUD 1945, maka permohonan para pemohon sepanjang pengujian material tidak beralasan dan harus ditolak.

\section{Simpulan}

Berdasarkan pembahasan dapat disimpulkan bahwa, "secara yuridis eksekusi pidana mati di Indonesia dilaksanakan dengan ditembak sampai mati berdasarkan ketentuan UU No. 2 Pnps Tahun 1964". Hal ini ditegaskan kembali oleh MK dalam putusan No. 21/PUU-VI/2008 yang menolak mengganti cara eksekusi pidana mati dengan cara lain yang bersifat tidak menyiksa terpidana sebagaimana dimohon oleh para terpidana mati Bom Bali Amrozi cs. MK berpendapat bahwa eksekusi pidana mati berdasarkan Undang Undang ini megandung risiko terjadinya ketidaktepatan dalam pelaksanaan yang menimbulkan rasa sakit, namun hal itu bukan merupakan penyiksaan sebagaimana dimaksud Pasal 28 I UUD 1945.

\section{Daftar Pustaka}

Abu Tamrin. 2012. "Hukuman Mati dan Hak Asasi Manusia dalam Peraturan Perundang-undangan". www.legalitas.org. [17 Januari 2012].

Andi Hamzah. 2011. Hukum Acara Pidana Indonesia. Jakarta: Sinar Grafika. Edisi Kedua, Cetakan Kelima.

Andi Hamzah dan Sumangilepu. 1983. Pidana Mati di Indonesia di Masa Lalu, Kini dan Masa Depan. Jakarta: Ghalia Indonesia

Anonim. 2008. Putusan MK No. 21/PUU-VI/2008.

Friedman, Lawrence M. 1977. Law and Society: An Introduction. New Yersey: Prentice Hall Inc. Englewood Cliffs

Komisi Nasional Hak Asasi Manusia 2008. Keputusan Sidang Paripurna Komnas HAM Nomor: 033/SP/IX/ 2008 dalam Sidang Paripurna Tanggal 23-24 September 2008.

Kompas. 2012. MK Kembali Tolak Menghapus Pidana Mati. [19 Juli 2012]

Leden Marpaung. 2010. Proses Penanganan Perkara Pidana (di Kejaksaan \& Pengadilan Negeri Upaya Hukum \& Eksekusi. Jakarta: Sinar Grafika. Bagian Kedua, Edisi Kedua.

Lilik Mulyadi. 2007. Hukum Acara Pidana Normatif, Teoritis, Praktik dan Permasalahannya. Bandung: Penerbit PT Alumni

Muladi. 1989. "Pidana Mati Ditinjau dari Sudut Tujuan Pemidanaan”. Makalah. Disampaikan pada Simposium Nasional "Realisasi Pidana Mati di Indonesia" yang diselenggarakan oleh Fakultas Hukum Universitas Muhammadiyah, Surakarta, 15 Juni 1989. Surakarta: Fakultas Hukum UMS

Roeslan Saleh. 1978. Masalah Pidana Mati. Jakarta: Aksara Baru

R. Sugandhi. 1981. K.U.H.P. Kitab Undang-Undang Hukum Pidana dengan Penjelasannya. Surabaya: Penerbit Usaha Nasional

Syamsul Hidayat. 2010. Pidana Mati di Indonesia. Yogyakarta: Genta Press

104 Yustisia Vol.1 No. 3 September - Desember 2012 Tinjauan Yuridis Eksekusi Pidana Mati di ... 